\title{
A reappraisal of the antibacterial action of cotrimoxazole in vitro
}

\author{
EVELYN L. LEWIS, J. D. ANDERSON, AND R. W. LACEY \\ From the Departments of Bacteriology, University of Bristol, and United Bristol Hospitals
}

SYNOPSIS The in-vitro action of the sulphamethoxazole/trimethoprim combination (cotrimoxazole) against coliforms, Proteus spp, and Staphylococcus aureus was re-examined. In nutrient broth the components of cotrimoxazole did not produce bacteriostatic synergy against most sulphonamideresistant and a significant proportion of sulphonamide-sensitive strains. Any bactericidal action appeared to be due to the trimethoprim component. After addition to urine the combination was only bacteriostatic against most coliforms and Proteus spp over six hours. Further clinical trials are needed to determine the circumstances under which cotrimoxazole is superior to either trimethoprim or sulphonamides against some infections, particularly of the urinary tract.

When a combination of sulphamethoxazole with trimethoprim (cotrimoxazole) was introduced in 1968 , its chief advantage was thought to be the antibacterial synergism between the two components (Darrell, Garrod, and Waterworth, 1968). This synergism was found to produce not only a more effective bacteriostatic effect (bacteriostatic synergy) when the drugs were used together rather than singly, but often a bactericidal activity (Darrell et al, 1968; Bushby, 1969). However, trimethoprim alone has been found to be as effective as the combination in treating urinary infections in outpatients (Brumfitt and Pursell, 1972), and has some bactericidal activity in vitro (Darrell et al, 1968). These findings prompted us to re-examine the activity of sulphamethoxazole and trimethoprim in vitro. We have already reported some results of the bactericidal action over $24 \mathrm{hr}$ (Lewis and Lacey, 1973). Here we have extended our observations that in nutrient broth the bacteriostatic synergy is unreliable and we have found that any bactericidal action resulting from the combination seems to be due to the trimethoprim component. Furthermore, cotrimoxazole is rarely bactericidal in urine. We therefore suggest that the advisability of invariably combining the drugs in treatment should be subjected to further clinical evaluation. Combined therapy increases the cost and the danger of toxic effects (Brumfitt and Pursell, 1972) and presents problems for the laboratory in sensitivity testing.

Received for publication 24 October 1973.

\section{Materials and Methods}

\section{ORGANISMS}

Cultures of coliforms, Proteus spp, and Staphylococcus aureus were obtained from infected material of hospital and non-hospital patients. Care was taken to avoid replicate isolates of the same strain. Approximately $70 \%$ of the coliforms were E. coli, $20 \%$ Klebsiella spp, and 10\% Enterobacter spp. Since the relevant properties of these three organisms were similar, the group will be referred to as 'coliforms'. E. coli strain CN 314 was supplied by Burroughs Wellcome, Beckenham, Kent. All the bacteria were sensitive to trimethoprim (MIC < $1.6 \mu \mathrm{g} / \mathrm{ml}$ ) but of variable sulphonamide sensitivity. Resistance to sulphonamides was defined as MIC $>200 \mu \mathrm{g}$ sulphamethoxazole $/ \mathrm{ml}$.

DETERMINATION OF MINIMUM INHIBITORY CONCENTRATION (MIC)

Sulphamethoxazole and trimethoprim were incorporated in doubling dilutions singly or in combination (usually in a ratio of 1 part trimethoprim: 20 parts sulphamethoxazole) into plates containing Oxoid diagnostic sensitivity test agar with the addition of $5 \%(\mathrm{v} / \mathrm{v})$ lysed horse blood. The plates were spot-inoculated with 10-20 colony-forming units of each culture and then incubated for $24 \mathrm{hr}$ at $37^{\circ} \mathrm{C}$. The endpoint was defined as the concentration that completely inhibited growth. Bacteriostatic synergy was defined as a four-fold or more reduction in the level of trimethoprim required to inhibit growth on 
the addition of sulphamethoxazole. For example, if the growth of a culture was inhibited by $1 \mu \mathrm{g}$ trimethoprim $/ \mathrm{ml}$ or $20 \mu \mathrm{g}$ sulphamethoxazole $/ \mathrm{ml}$, synergy would be indicated by inhibition of growth by $0.25 \mu \mathrm{g}$ trimethoprim combined with $5 \mu \mathrm{g}$ of sulphamethoxazole $/ \mathrm{ml}$. (A two-fold reduction denotes additive antibiotic action rather than synergy.)

Sulphamethoxazole and trimethoprim lactate were obtained from Burroughs Wellcome, Beckenham, Kent.

DETERMINATION OF MINIMUM BACTERICIDAL CONCENTRATIONS

Sulphamethoxazole and/or trimethoprim were added generally to final levels of 32 times that of the MIC to broths (Oxoid no. 2) containing 5\% (v/v) lysed horse red cells and stored overnight at $4^{\circ} \mathrm{C}$. After prewarming to $37^{\circ} \mathrm{C}$, each was then inoculated with an overnight broth culture of the test organism to a final cell density of $10^{4} / \mathrm{ml}$. The broths were sampled immediately and then at intervals by spreading a loopful $(0.01 \mathrm{ml})$ on nutrient agar plates by the method of Darrell et al (1968). Several cultures were also sampled by spreading $0.025 \mathrm{ml}$ over the surface of nutrient agar plates. These methods of sampling were adopted (a) to dilute out residual drugs, (b) to enable an easy check on the presence of contaminants to be made, and (c) to make our results comparable with those of Darrell et al (1968). The broths were considered to be free of sulphonamide and trimethoprim inhibitors because some cultures of Staph. aureus were destroyed by as little as $0.4 \mu \mathrm{g}$ trimethoprim $/ \mathrm{ml}$ or $0.4 \mu \mathrm{g}$ trimethoprim $/ \mathrm{ml}$ and $8 \mu \mathrm{g}$ sulphamethoxazole $/ \mathrm{ml}$ (for example see table IV). Sulphamethoxazole alone was bacteriostatic at levels as low as $8 \mu \mathrm{g} / \mathrm{ml}$. Effective bactericidal action was defined as the reduction in the number of viable bacteria to $10 \%$ or less of the inoculum. In cultures that were not completely killed by the drugs, a proportion of the surviving organisms were checked for their identity.

\section{BEHAVIOUR OF ORGANISMS IN HUMAN}

URINE

Twenty-four-hr collections of midstream urine from a healthy individual were sterilized by filtration and then pooled. Sulphamethoxazole $(1 \mathrm{mg} / \mathrm{ml})$ and trimethoprim $(50 \mu \mathrm{g} / \mathrm{ml})$ were added to $25 \mathrm{ml}$ aliquots (producing little change in $\mathrm{pH}$ ) and then bacteria were added to a final density of between about $10^{3}$ and $10^{4}$ organisms $/ \mathrm{ml}$. The inoculated urine was immediately sampled for viable bacteria (Miles and Misra, 1938) on MacConkey agar and then after two, four, six, and 24 hours' incubation at $37^{\circ} \mathrm{C}$. All experiments were done in duplicate, and the arithmetic means of the results were calculated.
Counts on several of the inoculated urine samples were confirmed by an independent worker. In other experiments, urine was collected from each of two healthy subjects on the third day of a course of treatment with cotrimoxazole (two tablets Septrin, Burroughs Wellcome, twice a day), pooled, and then treated as above. Controls included urine inoculated with the same bacteria but containing no antibacterial agents; counts of viable organisms in these were usually between $10^{7}$ and $10^{9} / \mathrm{ml}$ after $24 \mathrm{hr}$ at $37^{\circ} \mathrm{C}$.

\section{Results}

\section{BACTERIOSTATIC SYNERGY IN NUTRIENT} AGAR

The components of cotrimoxazole were not synergistic against nearly all sulphonamide-resistant coliforms and staphylococci, and a considerable minority of sulphonamide-sensitive coliforms, staphylococci, and Proteus spp (table I).

\begin{tabular}{|c|c|c|c|}
\hline Organism & $\begin{array}{l}\text { Reaction to } \\
\text { Sulphonamide }\end{array}$ & No. Tested & $\begin{array}{l}\text { Percentage } \\
\text { Showing } \\
\text { Bacteriostatic } \\
\text { Synergy }\end{array}$ \\
\hline $\begin{array}{l}\text { Staphylococcus } \\
\text { aureus }\end{array}$ & $\begin{array}{l}\mathbf{R} \\
\mathbf{S}\end{array}$ & $\begin{array}{l}14 \\
45\end{array}$ & $\begin{array}{r}7 \\
85\end{array}$ \\
\hline Coliforms & $\begin{array}{l}\mathbf{R} \\
\mathbf{S}\end{array}$ & $\begin{array}{l}56 \\
48\end{array}$ & $\begin{array}{r}7 \\
75\end{array}$ \\
\hline Proteus spp & $\mathbf{S}$ & 10 & 60 \\
\hline
\end{tabular}

Table I Bacteriostatic synergy between sulphamethoxazole and trimethoprim against strains of Staphylococcus aureus, coliforms, and Proteus spp

${ }^{1} R=$ resistant $(\mathrm{MIC}>200 \mu \mathrm{g} / \mathrm{ml}), \mathrm{S}=$ sensitive

'Synergy defined in Methods

BACTERICIDAL ACTION OF COTRIMOXAZOLE IN NUTRIENT BROTH

The reliability of the method was demonstrated by examining the bactericidal action of cotrimoxazole

\begin{tabular}{|c|c|c|c|c|c|}
\hline \multirow[t]{2}{*}{ Organism } & \multirow[t]{2}{*}{$\begin{array}{l}\text { Reaction to } \\
\text { Sulphonamide }\end{array}$} & \multirow[t]{2}{*}{$\begin{array}{l}\text { No. } \\
\text { Tested }\end{array}$} & \multicolumn{3}{|c|}{$\begin{array}{l}\text { No. Cultures } \\
\text { Destroyed by } \\
\text { Cotrimoxazole at }\end{array}$} \\
\hline & & & $2 \mathrm{Hr}$ & $4 H r$ & $6 \mathrm{Hr}$ \\
\hline $\begin{array}{l}\text { Staphylococcus } \\
\text { aureus }\end{array}$ & $\begin{array}{l}\mathbf{R} \\
\mathbf{S}\end{array}$ & $\begin{array}{l}6 \\
9\end{array}$ & $\begin{array}{l}2 \\
2\end{array}$ & $\begin{array}{l}4 \\
8\end{array}$ & $\begin{array}{l}5 \\
9\end{array}$ \\
\hline Proteus spp & $\mathbf{S}$ & 10 & 0 & 0 & 0 \\
\hline Escherichia coli & $\begin{array}{l}\mathbf{R} \\
\mathbf{S}\end{array}$ & $\begin{array}{r}7 \\
10\end{array}$ & $\begin{array}{l}0 \\
0\end{array}$ & $\begin{array}{l}0 \\
1\end{array}$ & $\begin{array}{l}0 \\
1\end{array}$ \\
\hline Klebsiella spp & $\mathbf{S}$ & 1 & 0 & 0 & 0 \\
\hline Enterobacter spp & $\mathbf{S}$ & 2 & 0 & 0 & 0 \\
\hline
\end{tabular}

Table II Bactericidal action of cotrimoxazole against strains of Staphylococcus aureus, coliforms, and Proteus spp in nutrient broth

See footnote to table I

Bactericidal action defined in Methods 
on three strains each of Staph. aureus, E. coli, and Proteus spp on between three and six occasions. Results were similar for all the strains when tested at two, four, and six hours. But at $24 \mathrm{hr}$ results were sometimes variable. To see if this variation at $24 \mathrm{hr}$ could be due to resistant mutants occurring in some cultures and not in others, the MICs of colonies from the 24-hr cultures were compared with those of the wild strains. There was no significant increase of resistance to the combination.
The bactericidal action of cotrimoxazole was variable towards different species; 14 out of 15 isolates of Staph. aureus were efficiently destroyed by six hours. None of the 10 Proteus isolates and only one of 20 coliforms showed destruction to $<10 \%$ of the inoculum (table II). The coliform that was efficiently destroyed was the strain CN 314 . Although results of viable counts at $24 \mathrm{hr}$ for individual srains were rather variable, they were generally, similar to those at six hours. Out of 50 coliforms

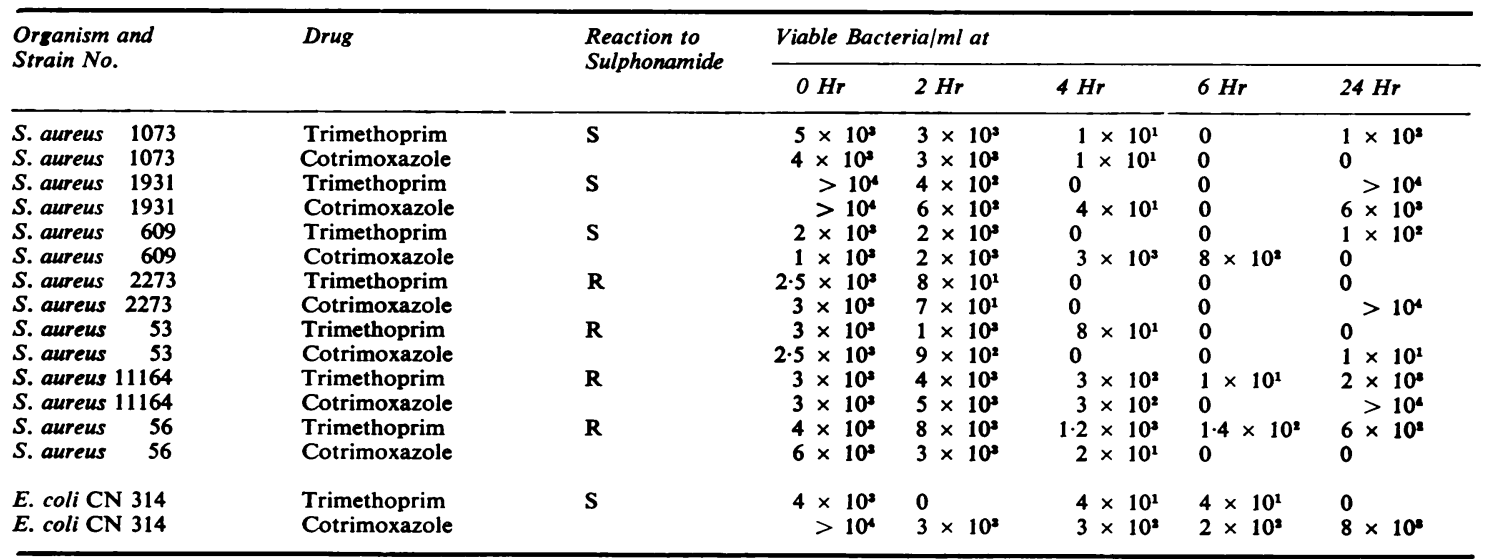

Table III Comparison of the rate of destruction of seven strains of Staphylococcus aureus and of one $\mathrm{E}$. coli by trimethoprim $(1.6 \mu \mathrm{g} / \mathrm{ml})$ and by cotrimoxazole $(1.6 \mu \mathrm{g}$ trimethoprim and $32 \mu \mathrm{g}$ sulphamethoxazole/ml)

\begin{tabular}{|c|c|c|c|c|c|c|c|}
\hline \multirow{2}{*}{$\begin{array}{l}\text { Strain No. } \\
\text { (Reaction to } \\
\text { Sulphonamide) }\end{array}$} & \multicolumn{2}{|c|}{ Concentration $(\mu \mathrm{g} / \mathrm{ml})$ of } & \multicolumn{5}{|c|}{ No. of Colonies per Plate at $^{1}$} \\
\hline & Sulphamethoxazole & Trimethoprim & $\mathrm{OHr}$ & $2 \mathrm{Hr}$ & $4 \mathrm{Hr}$ & $6 \mathrm{Hr}$ & $24 H r$ \\
\hline R3 (resistant) & $\begin{array}{r}8 \\
32 \\
8 \\
32 \\
128 \\
32 \\
128 \\
512 \\
128 \\
256 \\
1024 \\
256\end{array}$ & $\begin{array}{r}0.4 \\
0.4 \\
1.6 \\
1.6 \\
1.6 \\
6.4 \\
6.4 \\
6.4 \\
25.6 \\
12.8 \\
12.8 \\
51.2\end{array}$ & $\begin{array}{r}64 \\
19 \\
52 \\
18 \\
63 \\
>\quad 39 \\
69 \\
33 \\
54 \\
16 \\
70 \\
50\end{array}$ & $\begin{array}{r}80 \\
23 \\
62 \\
32 \\
110 \\
40 \\
143 \\
75 \\
78 \\
38 \\
86 \\
46\end{array}$ & $\begin{array}{r}50 \\
130 \\
26 \\
49 \\
19 \\
>200 \\
183 \\
>200 \\
85 \\
>200 \\
50 \\
120\end{array}$ & $\begin{array}{r}>200 \\
52 \\
37 \\
8 \\
130 \\
185 \\
>200 \\
60 \\
70 \\
86 \\
133 \\
>200\end{array}$ & $\begin{array}{l}C^{2} \\
C \\
C \\
C \\
C \\
S C^{2} \\
>200 \\
S^{2} \\
S C^{2} \\
S C\end{array}$ \\
\hline 1073 (sensitive) & $\begin{array}{r}8 \\
32 \\
8 \\
32 \\
128 \\
32 \\
128 \\
512 \\
256 \\
1024 \\
256\end{array}$ & $\begin{array}{r}0.4 \\
0.4 \\
1.6 \\
1.6 \\
1.6 \\
6.4 \\
6.4 \\
25.6 \\
12.8 \\
12.8 \\
51.2\end{array}$ & $\begin{array}{l}>200 \\
>200 \\
>200 \\
>200 \\
>200 \\
>200 \\
>200 \\
>200 \\
>200 \\
>200 \\
>200\end{array}$ & $\begin{array}{r}121 \\
100 \\
92 \\
73 \\
70 \\
73 \\
66 \\
90 \\
118 \\
103 \\
98\end{array}$ & $\begin{array}{r}10 \\
12 \\
26 \\
9 \\
6 \\
7 \\
9 \\
24 \\
14 \\
10 \\
10\end{array}$ & $\begin{array}{l}1 \\
0 \\
1 \\
4 \\
1 \\
1 \\
1 \\
1 \\
1 \\
2 \\
3\end{array}$ & $\begin{array}{r}90 \\
65 \\
150 \\
90 \\
0 \\
0 \\
0 \\
0 \\
1 \\
0 \\
0\end{array}$ \\
\hline
\end{tabular}

Table IV Effect of various concentrations and proportions of sulphamethoxazole and trimethoprim on a strain of E. coli $(R 3)$ and a strain of Staphylococcus aureus (1073) in nutrient broth

${ }^{1} A$ standard loopful $(0.01 \mathrm{ml})$ was spread over the surface of agar plates.

$\mathrm{C}^{2}=$ confluent; $\quad \mathrm{SC}^{2}=$ semi-confluent 


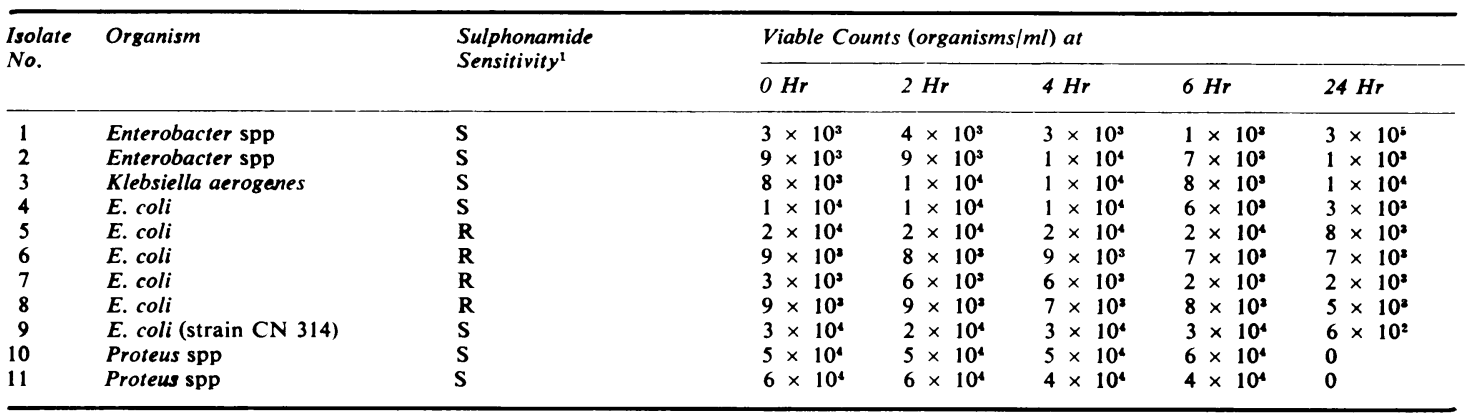

Table V Effect of cotrimoxazole (1 mg sulphamethoxazole, $50 \mu \mathrm{g}$ trimethoprim/ml) upon clinical isolates of Enterobacteriaceae in urine

${ }^{1}$ See footnote to table I

\begin{tabular}{|c|c|c|c|c|c|c|c|c|c|c|c|}
\hline \multirow{2}{*}{$\begin{array}{l}\text { Isolate } \\
\text { No }\end{array}$} & \multirow[t]{2}{*}{ Organism } & \multirow{2}{*}{$\begin{array}{l}\text { Sulphonamide } \\
\text { Sensitivity }\end{array}$} & \multirow[t]{2}{*}{ Subject } & \multicolumn{8}{|c|}{ Viable Counts (organisms $/ \mathrm{ml}$ ) } \\
\hline & & & & $\mathrm{OHr}$ & & $2 \mathrm{Hr}$ & & $4 \mathrm{Hr}$ & & $6 \mathrm{Hr}$ & $24 \mathrm{Hr}$ \\
\hline 1 & Enterobacter spp & $\mathbf{S}$ & R.W.L. & $1.2 \times$ & $10^{4}$ & $1.0 \times$ & $10^{4}$ & $5 \cdot 2 \times$ & $10^{4}$ & $4.6 \times 10^{3}$ & 0 \\
\hline 2 & Enterobacter spp & $\mathbf{S}$ & R.W.L. & $1 \cdot 2 \times$ & $10^{5}$ & $1 \cdot 1 \times$ & $10^{5}$ & $5.0 \times$ & $10^{4}$ & $2.6 \times 10^{4}$ & $8.0 \times 10^{2}$ \\
\hline 3 & Klebsiella aerogenes & $\mathbf{S}$ & R.W.L. & $9.0 \times$ & $10^{4}$ & $7.0 \times$ & $10^{4}$ & $3.4 \times$ & $10^{4}$ & $1.7 \times 10^{4}$ & $4.0 \times 10^{2}$ \\
\hline 4 & Escherichia coli & $\mathbf{S}$ & R.W.L. & $7.0 \times$ & $10^{4}$ & $7.6 \times$ & $10^{4}$ & $3 \cdot 2 \times$ & $10^{4}$ & $2.4 \times 10^{4}$ & $8.8 \times 10^{3}$ \\
\hline 5 & E. coli & $\mathbf{R}$ & R.W.L. & $5.6 \times$ & $10^{4}$ & $8.4 \times$ & $10^{4}$ & $7 \cdot 8 \times$ & $10^{4}$ & $6.8 \times 10^{4}$ & $9.6 \times 10^{3}$ \\
\hline 6 & E. coli & $\mathbf{R}$ & J.D.A. & $2.4 \times$ & $10^{4}$ & $2 \cdot 3 \times$ & $\times 10^{4}$ & $2 \cdot 2 \times$ & $10^{3}$ & $4.0 \times 10^{2}$ & 0 \\
\hline 7 & E. coli & $\mathbf{R}$ & J.D.A. & $8.4 \times$ & $10^{4}$ & $7.6 \times$ & $10^{4}$ & $3.2 \times$ & $10^{4}$ & $1.3 \times 10^{4}$ & 0 \\
\hline 8 & E. coli & $\mathbf{R}$ & J.D.A. & $4.4 \times$ & $10^{4}$ & $5.0 \times$ & $10^{4}$ & $4.8 \times$ & $10^{4}$ & $2.6 \times 10^{4}$ & 0 \\
\hline 9 & E. coli strain CN 314 & $\mathbf{S}$ & J.D.A. & $1.5 \times$ & $10^{5}$ & $1.1 \times$ & $\times 10^{5}$ & $7.6 \times$ & $10^{3}$ & $3.8 \times 10^{3}$ & $2.4 \times 10^{3}$ \\
\hline 10 & Proteus spp & $\mathbf{S}$ & J.D.A. & $5.4 \times$ & $10^{4}$ & $6.8 \times$ & $10^{4}$ & $4.8 \times$ & $10^{4}$ & $1.3 \times 10^{4}$ & 0 \\
\hline 11 & Proteus spp & $\mathbf{S}$ & J.D.A. & $6.4 \times$ & $10^{4}$ & $6.2 \times$ & $\times 10^{4}$ & $7.0 \times$ & $10^{4}$ & $2.9 \times 10^{4}$ & 0 \\
\hline
\end{tabular}

Table VI Effect of urine obtained from healthy individuals receiving a course of treatment with cotrimoxazole upon various clinical isolates of Enterobacteriaceae

${ }^{1}$ See footnote to table I

only seven were efficiently destroyed (to $<10 \%$ ) at $24 \mathrm{hr}$, and out of 38 staphylococci 34 were destroyed. The 14 staphylococci and the one coliform killed by cotrimoxazole within six hr were also destroyed by trimethoprim alone at the same concentration $(1.6 \mu \mathrm{g} / \mathrm{ml})$ as that used in cotrimoxazole. Results for seven of the staphylococci and the one $E$. coli strain to be destroyed are shown in table III. Sulphamethoxazole alone was always bacteriostatic. It therefore seems that the bactericidal activity of cotrimoxazole is due to the trimethoprim component. Alteration in the ratio of trimethoprim to sulphamethoxazole or increasing the concentrations of the drugs more than 10-fold had little influence on the bactericidal activity of the mixture, at least over six hr (table IV).

\section{ACTIVITY OF COTRIMOXAZOLE IN URINE}

The activity of cotrimoxazole in urine was found to be mainly bacteriostatic. Of nine coliforms and two Proteus spp tested, all survived in undiminished numbers for six hr in urine containing cotrimoxazole, regardless of their sulphonamide sensitivity (table V).
The two Proteus isolates, but none of the coliforms, were destroyed in 24 hours.

Urine obtained from healthy individuals receiving therapeutic doses of cotrimoxazole also produced very little bactericidal action within six hr, although some bactericidal activity was found at $24 \mathrm{hr}$ (table VI).

\section{Discussion}

Reasons for the differences in our results from those obtained by other workers are uncertain, since the methods used for some of the experiments were similar. The discrepancy in bactericidal activity of the combination for our strains and those of Darrell et al (1968) could be due to differences in strains (the latter tested only four strains for bactericidal effect). Strain differences may also account for the discrepancy between our findings and those of Bushby (1969), because the only coliform (strain $\mathrm{CN} 314$ ) that we have found to be reliably destroyed within six hr by cotrimoxazole was obtained from his laboratory. 
One advantage claimed for using a mixture of trimethoprim and sulphamethoxazole is in the prevention of resistance of bacteria to both drugs simultaneously. The value of this effect, however, is less than it might appear, because (1) many coliforms, Proteus spp, and staphylococci are already resistant to sulphonamides; (2) trimethoprim-resistant mutants with normal growth properties are difficult to isolate in vitro, even in strains already resistant to sulphonamides except for Strep. faecalis (Lewis and Lacey, 1973); (3) trimethoprim resistance has remained relatively uncommon in clinical strains, including those resistant to sulphonamides (Lacey, Gillespie, Bruten, and Lewis, 1972; Lewis and Lacey, 1973); (4) if resistance to trimethoprim does become common in coliforms, we expect that it will be mediated by $\mathbf{R}$ factors-one such $\mathrm{R}$ factor that determines resistance to trimethoprim also confers resistance to sulphonamides and has recently been detected in strains isolated in London (Fleming, Datta, and Grüneberg, 1972).

We do not dispute that combinations of trimethoprim and sulphamethoxazole are of value in treating some infections. The two drugs show bacteriostatic synergy against many organisms. But the use of the combination when a bactericidal agent is called for, and the efficiency of the combination in preventing the acquisition of drug resistance, calls for further clinical evaluation.

We thank Professor W. A. Gillespie for helpful advice. The work was supported in part by grants to Professor W. A. Gillespie from the Medical Research Committee of the United Bristol Hospitals. We are grateful to Mrs M. A. Sellin, M Sc, for help with some of the technical aspects of this study.

\section{References}

Brumfitt, W., and Pursell, R. (1972). Double-blind trial to compare ampicillin, cephalexin, co-trimoxazole, and trimethoprim in treatment of urinary infection. Brit. med.J., 2, 673-676.

Bushby, S. R. M. (1969). Combined antibacterial action in vitro of trimethoprim and sulphonamides. Postgrad. med. J., 45, Suppl. (Nov.), 10-18.

Darrell, J. H., Garrod, L. P., and Waterworth, P. M. (1968). Trimethoprim: laboratory and clinical studies. J. clin. Path., 21, 202-209.

Fleming, M. P., Datta, N., and Grüneberg, R. N. (1972). Trimethoprim resistance determined by $\mathbf{R}$ factors. Brit. med. J., 1, 726-728.

Lacey, R. W., Gillespie, W. A., Bruten, D. M., and Lewis, E. L. (1972). Trimethoprim-resistant coliforms. Lancet, 1, 409-410.

Lewis, E. L., and Lacey, R. W. (1973). Present significance of resistance to trimethoprim and sulphonamides in coliforms, Staphylococcus aureus and Streptococcus faecalis. J. clin. Path., 26, 175-180.

Miles, A. A., and Misra, S. S. (1938). The estimation of the bactericidal power of blood. J. Hyg. (Lond.), 38, 732-749. 